\title{
PARCELACJA WSI W OKRESIE MIĘDZYWOJENNYM I JEJ REPERKUSJE OSADNICZE NA PRZYKLADZIE FOLWARKÓW ORZESZKÓW, WIELENIN I ZIELEŃ
}

Zarys treści: W artykule przedstawiono wyniki badań nad procesem parcelacji majątków folwarcznych, zlokalizowanych w rejonie Uniejowa, w okresie międzywojennym. Szczegółowe analizy objęły trzy jednostki osadnicze położone w dawnej gminie Kościelnica: Orzeszków, Wielenin i Zieleń. W pierwszej części artykułu zobrazowano niektóre aspekty prawne procesów parcelacji, związane z implementacją reformy rolnej. W dalszej części opracowania, przedstawiono wyniki badań nad przebiegiem parcelacji wsi w gminie Kościelnica, z uwzględnieniem kwestii prawnych oraz przemian struktur przestrzennych osadnictwa.

Słowa kluczowe: geografia historyczna, osadnictwo, wieś, folwarki, parcelacja, reformy rolne, okres międzywojenny, gmina Kościelnica

\section{WPROWADZENIE}

Jednym z najbardziej palących problemów społeczno-gospodarczych Polski w pierwszych latach po zakończeniu pierwszej wojny światowej była kwestia chłopska. Trudna sytuacja na wsi stanowiła pokłosie nie tylko zniszczeń wywołanych działaniami militarnymi, ale przede wszystkim była wynikiem długotrwałych

* Monika Cepil, mgr, doktorantka, Uniwersytet Łódzki, Wydział Nauk Geograficznych Katedra Geografii Politycznej, Historycznej i Studiów Regionalnych, 90-142 Łódź, ul. Kopcińskiego 31, e-mail: monika_cepil@wp.pl.

** Tomasz Figlus, dr, adiunkt, Uniwersytet Łódzki, Wydział Nauk Geograficznych, Katedra Geografii Politycznej, Historycznej i Studiów Regionalnych, 90-142 Łódź, ul. Kopcińskiego 31, e-mail: tomasz.figlus@geo.uni.lodz.pl. 
zaniedbań i błędów w polityce prowadzonej przez poszczególnych zaborców. $Z$ tego względu władze II Rzeczypospolitej Polskiej poświęciły wiele uwagi zagadnieniom reform rolnych, mających na celu odbudowę polskiego rolnictwa i poprawę struktury agrarnej, cechującej się dużym rozwarstwieniem własnościowym.

W literaturze przedmiotu rzadko podejmowano do tej pory problem przemian strukturalnych wsi w środkowej Polsce, w okresie międzywojennym. Zagadnienie to było natomiast uwzględniane $\mathrm{w}$ różnych opracowaniach o szerokim spektrum tematycznym, ukierunkowanych na omówienie rozwoju wsi, w kontekście realizacji reform rolnych, czego przykładem mogą być prace M. Mieszczankowskiego $\mathrm{i} \mathrm{K}$. Konopki ${ }^{1}$. W badaniach geograficzno-historycznych osadnictwa, analizie poddawano proces parcelacji w kontekście jego skutków ruralistycznych, najczęściej o dość szerokiej skali przestrzennej, obejmującej większe regiony administracyjne (np. w pracach A. Prochownik, D. Kowalik-Bodzak²). Mało jest nadal opracowań traktujących wąsko o kwestiach parcelacyjnych, w odniesieniu do pojedynczych jednostek osadniczych czy też kluczy majątkowych, co pozwoliłoby prześledzić specyfikę tych procesów, uchwycić uwarunkowania, dokładny przebieg oraz reperkusje. Biorąc pod uwagę dostępne materiały źródłowe w Archiwum Państwowym w Łodzi, autorzy artykułu postanowili zbadać przebieg i skutki parcelacji majątków wiejskich, w okresie międzywojennym, w okolicach Uniejowa, a wyniki badań potraktować, jako swoiste studium mikroregionalne oraz bazę do dalszych analiz porównawczych.

Zakres przestrzenny badań obejmuje lata 1919-1925. Badane majątki (Orzeszków, Wielenin i Zielenin/Zieleń3 ${ }^{3}$ w okresie międzywojennym rozmieszczone były na obszarze nieistniejącej już gminy Kościelnica, która funkcjonowała $\mathrm{w}$ okresie międzywojennym $\mathrm{w}$ powiecie tureckim, w granicach województwa łódzkiego, powołanego do życia zgodnie z ustawą administracyjną z 1919 r. ${ }^{4}$ Oprócz omawianych folwarków (jako autonomicznych punktów osadniczych) w skład gminy Kościelnica wchodziły następujące wsie: Aleksandrów, Brzeziny, Człopki Małe, Czopy Wielkie, Kościelnica, Orzeszków,

1 M. Mieszczankowski, Rolnictwo II Rzeczypospolitej, Książka i Wiedza, Warszawa 1983; K. Konopka, Mechanizm reform agrarnych w Drugiej Rzeczypospolitej Polskiej (19181939), Oficyna Wydawnicza Politechniki Białostockiej, Białystok 2010.

2 A. Prochownik, Przemiany struktury osadniczo-agrarnej wsi powiatu proszowickiego od polowy XIX wieku do 1960 r. (na wybranych przykładach), „Dokumentacja Geograficzna” 1965, z. 6; D. Kowalik-Bodzak, Wpływ podziału spadkowego, komasacji i parcelacji na zmiane uktadów przestrzennych wsi w powiecie puławskim od połowy XIX w., „Dokumentacja Geograficzna” 1964, z. 4.

3 T. Grabarczyk, A. Kowalska-Pietrzak, J. Szymczak, Uniejowskie strony-karty z przeszłości odległej, nieznanej i bliskiej gminy Uniejów, Łódź-Uniejów 2008, s. 164.

$4 \mathrm{M}$. Bandurka, Zmiany administracyjne i terytorialne ziem województwa łódzkiego w XIX $i X X$ w. /Wydanie II uzupełnione/, Łódź 1995, s. 78; T. Grabarczyk, A. Kowalska-Pietrzak, J. Szymczak, Uniejowskie strony..., Łódź-Uniejów 2008, s. 23. 
Ostrowsko, Spicymierz, Ubysław, Wielenin, Wieszczyce, Wola Przedmiejska i Zielenin. Według spisu powszechnego z 1921 r. gminę Kościelnica zamieszkiwało 3817 osób $^{5}$.

\section{UWARUNKOWANIA PRAWNE REFORM ROLNYCH W OKRESIE MIĘDZYWOJENNYM}

W dniu 10 lipca 1919 r. Sejm Ustawodawczy, pod naciskiem posłów z partii chłopskich, podjął uchwałę, która miała doprowadzić do przyjęcia ustawy o reformie rolnej. Ustawa ta została uchwalona 15 lipca 1920 r., w obliczu zagrożenia bytu państwowego. Rozpoczęto w ten sposób długotrwały proces zaspokojenia rosnących potrzeb, wynikających z niedostatku ziemi wśród ludności chłopskiej. Myślą przewodnią było założenie, aby wszystkie większe majątki ziemskie, będące własnością państwa, osób prywatnych i fundacji, rozdzielić między chłopów z pozostawieniem właścicielowi części dotychczasowego majątku ${ }^{6}$. Na mocy podjętych decyzji wprowadzona została zasada przymusowego wykupu ziemi od właścicieli ziemskich ${ }^{7}$. Pierwszeństwo w nabywaniu ziemi przysługiwało służbie folwarcznej, drobnym rolnikom, żołnierzom i bezrobotnym ${ }^{8}$. Ustawa z 1920 r., okazała się sprzeczna z Konstytucją marcową z 1921 r. Parcelacja majątków bez wypłacania adekwatnego odszkodowania właścicielom była niezgodna z zapisem głoszącym, że własność prywatna jest nienaruszalna9.

Zgodnie z zapisami ustawy z 1920 r. rozpoczął się proces parcelacji gruntów. W przypadku środkowej Polski, przymusowej parcelacji podlegały wszystkie majątki ziemskie o powierzchni przekraczającej 180 ha $^{10}$. Dotychczasowi właściciele otrzymali odszkodowania sięgające połowy ceny rynkowej wywłaszczonej

5 Skorowidz miejscowości Rzeczypospolitej Polskiej, województwo łódzkie, Warszawa 1925, t. II, s. 115-116.

6 Parcelacja i Osadnictwo (parę stów o reformie rolnej), Towarzystwo Oświaty Narodowej, Warszawa 1921, s. 3.

7 Tamże, s. 6; K. Konopka, Konieczność reform agrarnych w Drugiej Rzeczypospolitej Polskiej, „Economy and Management” 2009, nr 1, s. 11.

8 W. Ziętara, Spoleczny czy ekonomiczny charakter reform rolnych w Polsce w okresie między- $i$ powojennym, „Roczniki Naukowe Ekonomii Rolnictwa i Rozwoju Obszarów Wiejskich” 2015, t. 102, z. 1, s. 33.

9 Konstytucja Rzeczypospolitej Polskiej z dn. 17 marca 1921 r., art. 99 (Dz.U. 1921, nr 44, poz. 267); K. Firlej, Formy organizacyjne zagospodarowania..., s. 30, Cz. Noniewicz, Reforma rolna na Wileńszczyźnie..., s. 237.

${ }^{10}$ M. Machałek, Przemiany polskiej wsi w latach 1918-1989, „Klio. Czasopismo poświęcone dziejom Polski i powszechnym" 2013, t. 26 (3), s. 60; K. Firlej, Formy organizacyjne zagospodarowania ziem polskich na przestrzeni wieków, „Roczniki Ekonomiczne Kujawsko-Pomorskiej Szkoły Wyższej w Bydgoszczy" 2011, nr 4, s. 29-30; C. Noniewicz, Reforma rolna na Wileńszczyźnie w okresie międzywojennym, „Optimum. Studia Ekonomiczne” 2014, nr 6 (72), s. 237. 
ziemi $^{11}$. W związku z realizacją reformy, do parcelacji w gminie Kościelnica przeznaczono dawne dobra donacyjne, należące do rodziny Tollów. Majorat, utworzony po upadku powstania listopadowego ${ }^{12}$, przejęło Ministerstwo Rolnictwa i Dóbr Państwowych (dawne Ministerstwo Rolnictwa i Dóbr Koronnych) ${ }^{13}$. Warto dodać, że przed przejęciem przez rząd analizowanego majoratu, Aleksander Toll, działający w imieniu swojej matki, chciał sprzedać dobra Stęplew i Gąsiory (leżące poza gminą Kościelnica). Potencjalnymi kupcami mieli być Walentyn Pietrzak i Janusz Dzierżawski, jednak władze odmówiły przeprowadzenia transakcji ${ }^{14}$. Majątek w Stęplewie (730 ha) został zachowany przez prawnuka Karola von Tolla - Michała ${ }^{15}$. W latach 1920-1935 rozparcelowano dawne grunty folwarczne, należące pierwotnie do rodziny Tollów. Dobra znajdujące się w posiadaniu Państwa zostały, przez Ministerstwo Rolnictwa i Dóbr Państwowych, przekazane Głównemu Urzędowi Ziemskiemu, na rozdzielenie po wyłączeniu niezbędnych do innych celów obiektów państwowych ${ }^{16}$.

Kierownictwo i nadzór nad należytym przeprowadzeniem reformy rolnej należało do zadań Głównego Urzędu Ziemskiego. W sprawach związanych z wytwórczością rolniczą, Główny Urząd Ziemski działał w porozumieniu z Ministrem Rolnictwa i Dóbr Państwowych. Przy Głównym Urzędzie Ziemskim powołano także specjalny organ: tzw. Główną Komisję Ziemską. Władzami wykonawczymi w sprawach reformy rolnej, podległymi bezpośrednio Głównemu Urzędowi Ziemskiego, były Okręgowe Urzędu Ziemskie (dla analizowanego obszaru siedziba znajdowała się w Kaliszu). Powstać także miały powiatowe Urzędy Ziemskie i Gminne Komisje Ziemskie odpowiedzialne za przeprowadzenie ustawy na swoich terytoriach ${ }^{17}$. Wykupem ziemi od właścicieli, na cele parcelacyjne, zajmowały się powiatowe i okręgowe urzędy administracyjne. Właścicielom przysługiwało prawo wyboru, które grunty chcą zatrzymać, w ramach przysługującego im limitu obszarowego. Formalności związane z przyjęciem gruntów na cele parcelacyjne trwały około roku $^{18}$. Kolejnym etapem procesu parcelacji był podział ziem na indywidualne

${ }^{11}$ K. Konopka, Konieczność reform agrarnych ..., s. 12.

12 J. Kukulski, Generałowie carscy $i$ ich majątki ziemskie $w$ Królestwie Polskim (1835-1920), Warszawa 2007, s. 377; M. Cepil, T. Figlus, Geneza majoratu i stosunki osadnicze w dobrach rodziny Tollów pod Uniejowem, „Biuletyn Uniejowski” 2017, t. 6, s. 100.

${ }_{13}$ Ustawa z dn. 4 listopada 1918 r. w przedmiocie dóbr donacyjnych (Monitor Polski, nr 217, dn. 30 listopada 1918 r., Dz.U. Nr 15, poz. 35).

${ }^{14}$ M. Kłusek, Definicja nieruchomości ziemskiej $w$ aktach prawnych i orzecznictwie sądowym 20-lecia międzywojennego, „Studia z zakresu Prawa, Administracji i Zarządzania” 2015, t. 8, s. $102-103$.

${ }^{15}$ G. Myszkorowska-Olczak, Zespoły folwarczne na terenie gminy Uniejów, „Biuletyn Uniejowski" 2013, t. 2, s. 102.

${ }^{16}$ Ustawa z dn. 15 lipca 1920 r. o wykonaniu reformy rolnej (Dz.U. 1920, nr 70, poz. 462).

${ }_{17}$ Ustawa z dn. 6 lipca 1920 r. o organizacji urzędów ziemskich (Dz.U. 1920, nr 70, poz. 461).

${ }^{18}$ W. Ziętara, Społeczny czy ekonomiczny..., s. 34. 
działki osadnicze. Trzeba wspomnieć, że występowały dwa typy parcelacji: tzw. kolonizacja wewnętrzna, czyli tworzenie nowych, samodzielnych gospodarstw rolnych oraz parcelacja sąsiedzka, czyli uzupełnianie istniejących karłowatych działek $^{19}$. Zadaniem reformy było stworzenie takich gospodarstw rolnych, z których gospodarz mógłby się utrzymać, nie szukając innych prac zarobkowych ${ }^{20}$.

Po czterech latach od ogłoszenia w Dzienniku Ustaw nastąpiła nowelizacja ustawy, polegająca na stworzeniu systemu zachęt, skłaniających właścicieli ziemskich do parcelacji dobrowolnej ${ }^{21}$. Przyjęto 200 tys. ha w skali kraju, jako roczny kontyngent parcelacji. Jeśli okazałoby się, że fragmentacja terenu jest mniejsza od tego kontyngentu, to rząd był upoważniony to przeprowadzenia przymusowego rozparcelowania uzupełniającego ${ }^{22}$. Celem reformy było tworzenie samodzielnych gospodarstw, powiększenie mniejszych do wielkości pełnorolnych oraz wytyczenie terenów dla potrzeb edukacyjnych i administracyjnych. Nowelizacja ustawy okazała się korzystniejsza dla posiadaczy wielkich majątków ziemskich ${ }^{23}$. Pierwszeństwo w nabywaniu gruntów zastrzeżono dla robotników rolnych i małorolnych chłopów, co w rzeczywistości było fikcją, ze względu na bardzo wysokie ceny ziemi ${ }^{24}$.

\section{PROCESY PARCELACYJNE W GMINIE KOŚCIELNICA I ICH SKUTKI OSADNICZE}

Autorzy analizę przebiegu omawianego procesu zaczną od krótkiego opisu geograficzno-historycznego badanych majątków ziemskich. Folwark w Zieleninie (ryc. 1) o powierzchni 427 morgów (239,12 ha) zlokalizowany był na zachód od Uniejowa i składał się z dwóch części. Pierwszy fragment obejmował grunty sąsiadujące z wsią Spicymierz, leśnictwem Zieleń, gruntami wsi Człopy, Łękiem Kościelnym i dobrami miasta Uniejów. W skład drugiej części wchodziły grunty sąsiadujące z wsią Człopy, leśnictwem Czarny Las oraz gruntami majątku Wielenin ${ }^{25}$. Grunty w dobrach Zielenin dzierżawiły rodziny bezrolne ze Spicymierza oraz wsi Zielenin ${ }^{26}$.

\footnotetext{
${ }^{19}$ Ustawa z dn. 15 lipca 1920 r. o wykonaniu reformy rolnej (Dz.U. 1920, nr 70, poz. 462).

${ }^{20}$ Parcelacja i Osadnictwo..., s. 4.

${ }^{21}$ Dziennik Ustaw nr 1, poz. 1 z 1926 r., Prawo rolne, wyd. III, Warszawa 2006, s. 33.

${ }^{22}$ Tamże; Cz. Noniewicz, Reforma rolna na Wileńszczyźnie..., s. 237.

${ }^{23}$ W. Ziętara, Społeczny czy ekonomiczny..., s. 33.

${ }^{24}$ K. Firlej, Formy organizacyjne zagospodarowania ..., s. 32.

${ }^{25}$ Archiwum Główne Akt Dawnych w Warszawie [dalej AGAD], Zbiór kartograficzny, Plan
} wsi i folwarku Zielenin z 1839 r., sygn. 185-1, ark. 27; Archiwum Państwowe w Łodzi [dalej APŁ], Okręgowy Urząd Ziemski w Piotrkowie [dalej OUZP], Sprawa parcelacji państwowego majattu Zieleń gmina Kościelnica, sygn. 594; APŁ, OUZP, Sprawa parcelacji majątku państwowego Zieleń-Ląki gmina Kościelnica, sygn. 596.

${ }^{26}$ APŁ, OUZP, Sprawa parcelacji państwowego majątku Zieleń gmina Kościelnica, sygn. 594. 


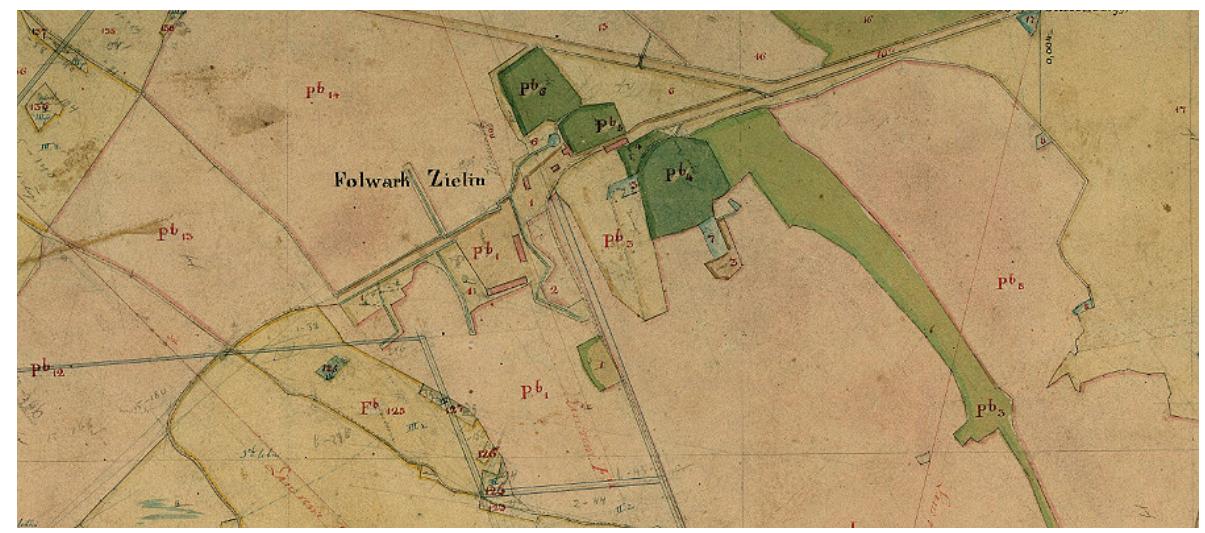

Ryc. 1. Plan wsi i folwarku Zielenin z 1839 r.

Źródło: AGAD, Zbiór kart., sygn. 185-1 ark. 27

Majątek w Orzeszkowie (ryc. 2) usytuowany był przy drodze z Uniejowa do Dąbia, a swoim kształtem przypominał prostokąt, o dłuższych bokach biegnących z północy na południe. Od północy graniczył z gruntami wsi Orzeszków, od południa z łąkami miejskimi Uniejowa, od wschodu z gruntami ornymi mieszkańców wsi Brzeziny, a od zachodu z polami wsi Orzeszków i Ostrowsko. Ogólna powierzchnia majątku wynosiła 538 mórg $(301,28 \mathrm{ha})^{27}$ : w tym ziemi ornej 495 mórg (227,20 ha), po 4 morgi (2,24 ha) zajmowała zabudowa oraz ogrody owocowe i warzywne, pozostałe 3 morgi (1,68 ha) obejmowały drogi, rowy i sadzawki ${ }^{28}$. Z ziem folwarcznych Orzeszkowa powstała Kolonia-Orzeszków ${ }^{29}$.

Folwark Wielenin (ryc. 2) od północy sąsiadował z wsią Dąbrowa, na zachodzie z gruntami wsi Czepów i Stanisławów oraz lasami państwowymi Uniejów, od południa z Brzezinami. Na wschód od zabudowań folwarcznych usytuowane były wsie Wielenin i Zaborów ${ }^{30}$. Obszar majątku wynosił 903 morgi (505,68 ha), z czego około 714 mórg (399,84 ha) obejmowały grunty orne, 120 mórg łąki (67,20 ha) a zabudowa stanowiła około 6 mórg (3,36 ha). Parcelacja miała także miejsce na tzw. Łąkach na Zieleniu, sąsiadujących od wschodu ze wsią Spicymierz, od południa z gruntami wsi Kaczki, a od północy i zachodu z lasami państwowymi. Łąki przed parcelacją dysponowały powierzchnią 123 morgi 23 pręty $(68,88 \mathrm{ha})^{31}$. W okresie międzywojennym nastąpiła także parcelacja łąk nazwanych Rudunki.

${ }^{27}$ APŁ, OUZP, Operat parcelacji majątku Orzeszków gmina Kościelnica, sygn. 498; AGAD, Zbiór kartograficzny, Mapa dóbr Uniejów położonych w Gubernii i Obwodzie Kaliskim, 1838, sygn. 249-9 ark. 5; G. Myszkorowska-Olczak, Zespoły folwarczne na terenie..., s. 106.

28 APŁ, OUZP, Operat parcelacji majątku Orzeszków gmina Kościelnica, sygn. 498.

${ }^{29}$ T. Grabarczyk, A. Kowalska-Pietrzak, J. Szymczak, Uniejowskie strony-karty ..., s. 103.

${ }^{30}$ AGAD, Zbiór kartograficzny, Mapa dóbr Uniejów położonych w Gubernii i Obwodzie Kaliskim, 1838, sygn. 249-9, ark. 5.

${ }^{31}$ APŁ, OUZP, Sprawa parcelacji majątku państwowego Wielenin gmina Kościelnica, sygn. 572. 
Położone one były przy szosie z Turka do Uniejowa i posiadały powierzchnię 105 mórg 43 pręty $(58,80 \text { ha) })^{32}$. Według spisu powszechnego z $1921 \mathrm{r}$. w majątkach mieściło się 8 budynków mieszkalnych, po trzy budynki w Orzeszkowie i Wieleninie oraz dwa w Zieleninie. Analizowane założenia folwarczne zamieszkiwało 309 osób ${ }^{33}$.

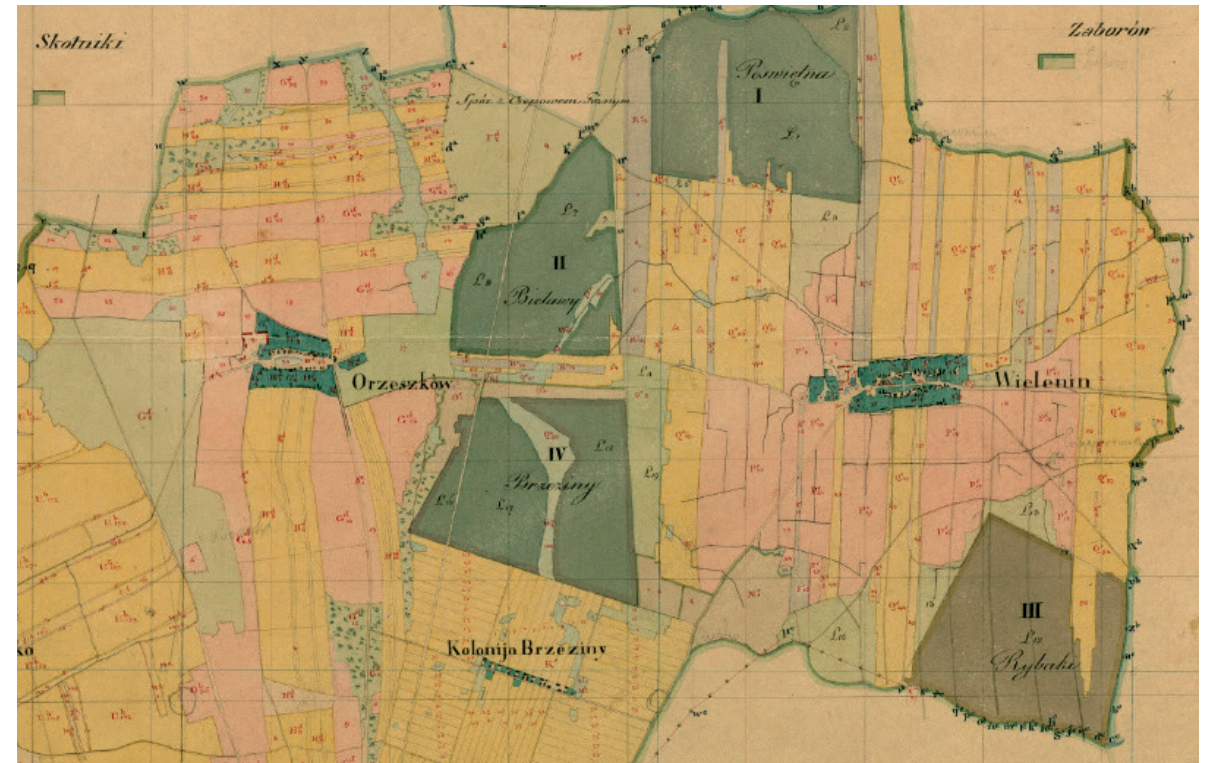

Ryc. 2. Planu wsi i gruntów folwarcznych Orzeszkowa i Wielenina. Stan z 1838 r.

Źródło: AGAD, Zbiór. kart., sygn. 249-9 ark. 5

Według wytycznych reformy rolnej, nabywcami ziemi mieli być chłopi oraz robotnicy rolni ${ }^{34}$, posiadający polskie obywatelstwo i wykazujący dostateczne przygotowanie zawodowe do prowadzenia działalności rolniczej. Pierwszeństwo w wykupie gruntów przysługiwało wojskowym armii polskiej i inwalidom wojennym oraz pracownikom rolnym, i służbie folwarcznej, a także chłopom, mieszkającym w sąsiedztwie rozparcelowanych terenów, a posiadającym karłowate gospodarstwa. O nowo wytyczone działki mogli się także starać absolwenci szkół rolniczych ${ }^{35}$.

W gminie Kościelnica nabywcami z zewnątrz byli zazwyczaj wojskowi i oficerowie. W Orzeszkowie grunty przyznano $\mathrm{m}$. in. mundurowym z Warszawy, Kalisza, Turku i Dobrej. Trzeba również podkreślić, że duża część rozparcelo-

\footnotetext{
${ }^{32}$ APŁ, OUZP, Sprawa parcelacji państwowego majątku Zieleń gmina Kościelnica, sygn. 594.

${ }^{33}$ Skorowidz miejscowości Rzeczypospolitej Polskiej..., s. 115-116.

${ }^{34}$ Cz. Noniewicz, Reforma rolna na Wileńszczyźnie..., s. 237.

${ }^{35}$ Ustawa z dn. 15 lipca 1920 r. o wykonaniu reformy rolnej (Dz.U. Nr 70, poz. 462).
} 
wanego majątku Orzeszków przeszła w posiadanie dawnej służby dworskiej z Orzeszkowa i Ostrowska. Większość nabywców deklarowała posiadanie umiejętności pracy na roli. Był to jeden z niezbędnych wymogów otrzymania ziemi ${ }^{36}$. Wśród osób chętnych do nabycia Łąk na Zieleniu dominowały osoby m. in.: ze Spicymierza, Brzezin i Ostrowska ${ }^{37}$.

Nabywcy ziemi mogli korzystać ze zróżnicowanej pomocy finansowej. Największy zakres pomocy przysługiwał osobom bezrolnym. Nabywcy byli zobowiązani do wpłaty 5\% zaliczki w momencie podpisywania umowy, właściciele drobnych gospodarstw wpłacali 10\% należnej sumy, a właściciele samodzielnych gospodarstw i nabywcy ośrodków gospodarczych wpłacali $25 \%$ całości. Kupcy korzystali także z możliwości wzięcia kredytu na zakup nowych gospodarstw ${ }^{38}$. Małorolni i bezrolni chłopi często zaciągali pożyczki, których jednak nie byli w stanie spłacić. Z tego względu większość kupujących stanowili bogaci chłopi zamieszkający w sąsiedztwie parcelowanego majątku ${ }^{39}$. Ceny poszczególnych działek były oparte na rzeczywistej wartości gruntów ${ }^{40}$.

W celu pozyskania działki należało złożyć podanie, według przyjętego wzoru, w Urzędzie Okręgowego Komisarza Ziemskiego ${ }^{41}$. W przypadku gminy Kościelnica zgłoszenia przyjmowane były w Powiatowym Urzędzie Ziemskim w Turku ${ }^{42}$. Kolejny etap rekrutacji polegał na przedstawieniu zaświadczenia o posiadanych kwalifikacjach, potwierdzonego przez Urząd Gminny, parafię lub Komisarza Ziemskiego. W zaświadczeniu wyszczególniało się również: narodowość, pochodzenie, zawód oraz czy nie ma przeszkód prawnych w nabyciu ziemi przez osadnika. Każdy indywidualnie sporządzał także wykaz następujących informacji: ile chce nabyć ziemi i jaką gotówką dysponuje, czy posiada jakieś własne budynki, materiał drzewny oraz czy posiada materiał siewny (ziarno) ${ }^{43}$.

Jedną z pierwszych czynności wprowadzania w życie reformy rolnej było sporządzenie raportu klasyfikacyjno-szacunkowego. Wykonanie raportu należało do zadań Okręgowego Urzędu Ziemskiego. Plan uwzględniał wskazanie robót melioracyjnych oraz szczegółową klasyfikację gruntu ${ }^{44}$. Prace melioracyjne polegały na uregulowaniu stosunków wodnych na istniejących już użytkach rolnych

\footnotetext{
${ }^{36}$ APŁ, OUZP, Operat parcelacji majątku Orzeszków gmina Kościelnica, sygn. 498.

${ }^{37}$ APŁ, Okręgowy Urząd Ziemski w Piotrkowie, W sprawie parcelacji łąk Zieleń tzw. część majątku Wielenin wieś Zieleń gm. Kościelnica tom I, sygn. 571.

${ }^{38}$ W. Ziętara, Społeczny czy ekonomiczny..., s. 34-35.

${ }^{39}$ K. Firlej, Formy organizacyjne zagospodarowania ..., s. 32.

${ }^{40}$ J.S. Langrod, Zarys administracji agrarnej w Polsce, Kraków-Warszawa 1939, s. 42.

${ }^{41}$ Parcelacja i Osadnictwo..., s. 8.

${ }^{42}$ APŁ, OUZP, Sprawa parcelacji państwowego majątku Orzeszków gmina Kościelnica, sygn. 498.

${ }^{43}$ Parcelacja i Osadnictwo..., s. 8.

${ }^{44}$ Ustawa z dn. 15 lipca 1920 r. o wykonaniu reformy rolnej (Dz.U. Nr 70, poz. 462).
} 
oraz przekształceniu nieużytków na grunty orne ${ }^{45}$. Ze względu na gleby, grunty przeznaczone na parcelację w Orzeszkowie podzielono na trzy klasy. Do pierwszej klasy zakwalifikowano grunty doskonałe do uprawy buraków i pszenicy, do drugiej klasy grunty żytnio-ziemniaczane, a do trzeciej klasy ziemie gorszej jakości ${ }^{46}$. W raporcie wyszczególniono również, które parcele nadają się do uprawy drzew owocowych. Zaznaczono również numery działek podmokłych. Klasyfikacja gruntów miała wpływ na cenę działki ${ }^{47}$. W Zieleninie grunty przeznaczone na parcelację podzielono na cztery klasy bonitacyjne, przy czym wyraźnie dominował udział gruntów reprezentujących klasę IV (tab. 1).

Tabela 1. Struktura gruntów przeznaczonych pod parcelację w folwarku Zielenin

\begin{tabular}{|c|c|}
\hline Klasa gruntu & Powierzchnia $w$ ha \\
\hline II & 21,28 \\
\hline III & 15,68 \\
\hline IV & 76,16 \\
\hline V & 22,96 \\
\hline
\end{tabular}

Źródło: APŁ, OUZP, Sprawa parcelacji państwowego majątku Zieleń gmina Kościelnica, sygn. 594.

W planach parcelacyjnych uwzględniano także wyłączenia z parcelacji czyli m. in.: cenne budowle, zabudowania folwarczne, drogi dojazdowe i polne. Większe budynki starano się przeznaczać na szkoły rolnicze, stacje doświadczalne oraz inne cele społeczne, przemysłowe i kościelne ${ }^{48}$. Warto dodać, że w okresie międzywojennym instytucją o dużym znaczeniu społecznym było szkolnictwo wiejskie, zwłaszcza rolnicze ${ }^{49}$. Powodem tego było dążenie do podniesienia kultury rolnej społeczeństwa ${ }^{50}$.

Według projektów dokonywano klasyfikacji szacunkowej gruntów, które zostały naniesione na kalkę, przez wyznaczonego przez urząd geometrę. Projekt parcelacji w Orzeszkowie (tab. 2) przewidywał 60 mórg (33,60 ha) na szkołę rolniczą, 5,5 mórg $(3,08)$ na szkołę powszechną, dla parafii Wilamów 12 mórg $(6,72$ ha), dla parafii

${ }^{45}$ W. Staniewicz, Zmiany w strukturze agrarnej Polski, „Ruch Prawniczy, Ekonomiczny i Socjologiczny" 1936, nr 4, s. 387.

${ }_{46}$ APŁ, OUZP, Operat parcelacji majątku Orzeszków gmina Kościelnica, sygn. 498.

${ }^{47}$ APŁ, OUZP, Operat przewłaszczeniowy Orzeszków gmina Kościelnica, sygn. 500.

${ }^{48}$ Ustawa z dn. 15 lipca 1920 r. o wykonaniu reformy rolnej (Dz.U. Nr 70, poz. 462).

${ }^{49} \mathrm{M}$. Biernacka, Oświata a spoleczno-kulturowe przeobrażenia wsi w okresie międzywojennym (na przykładzie wybranych społeczności), „Etnografia Polska” 1983, t. 27, z.1, s. 115.

${ }^{50}$ W. Staniewicz, Zmiany w strukturze agrarnej ..., s. 387. 
Uniejów 6 mórg $(3,36 \text { ha })^{51}$. W Orzeszkowie wyszczególniono przestrzeń dla straży pożarnej, która zasięgiem swego oddziaływania obejmowała także Ostrowska ${ }^{52}$.

Według pierwszych planów, sporządzonych dla majątku Zieleń z 1919 r. (tab. 2), z parcelacji miały zostać wyłączone: leśniczówka z zabudowaniami (34 morgi - 19,04 ha) i niwy szkolne (32 morgi - 17,92 ha). Wydzielono również grunty dla parafii w Spicymierzu (13 morgów - 7,28 ha) i Uniejowie (7 mórg $-3,92 \mathrm{ha}$ ) oraz dla domu ludowego w Spicymierzu 1 morgę ( $0,56 \mathrm{ha})$. Pod zalesienie przeznaczono 11 mórg (6,16 ha). Inspektor Okręgowy proponował także, aby pozostawić 60 mórg (33,60 ha) ziemi pod budowę cegielni. Tym sposobem na samodzielne gospodarstwa chłopskie przeznaczono 268 mórg $(150,08 \mathrm{ha})^{53}$.

Tabela 2. Areał gruntów folwarcznych i powierzchnia gruntów w hektarach wyłączonych z parcelacji na cele rolne w majątkach ziemskich gminy Kościelnica (stan na 1921 r.)

\begin{tabular}{|c|c|c|c|}
\hline Wyszczególnienie & Orzeszków & Wielenin & Zielenin \\
\hline $\begin{array}{c}\text { Obszar parcelowanego } \\
\text { majątku (w ha) }\end{array}$ & 301,28 & 505,68 & 239,12 \\
\hline Szkolnictwo & 36,68 & 18,62 & 17,92 \\
\hline Parafia & 10,08 & 14,13 & 11,20 \\
\hline Straż pożarna & 0,26 & 0,78 & - \\
\hline Inne & - & 0,7 & 25,76 \\
\hline
\end{tabular}

Źródło: opracowanie własne na podstawie: APŁ, OUZP, Operat parcelacji majątku Orzeszków gmina Kościelnica, sygn. 498, APŁ, OUZP, Sprawa parcelacji majątku państwowego Wielenin gmina Kościelnica, sygn. 572; APŁ, OUZP, Sprawa parcelacji państwowego majątku Zieleń gmina Kościelnica, sygn. 594.

W Wieleninie działkę o $\mathrm{nr} 22$ o powierzchni 10 mórg 132 pręty $(5,67$ ha) oddano na potrzeby parafii Wielenin, dla parafii Świnice przeznaczono 15 mórg 112 prętów $(8,46$ ha) w obrębie działki nr 19. Działkę o $\mathrm{nr} 18$ o powierzchni 1 morgi 247 prętów ( 0,70 ha) przeznaczono pod cmentarz. Dla szkoły podstawowej, znajdującej się na działce nr 21, przeznaczono 12 mórg 256 prętów (6,72 ha). Wytyczono także 1 morgę 39 prętów $(0,78 \text { ha) dla straży pożarnej (działka nr } 23)^{54}$. Warto wspomnieć, że straż pożarna w Wieleninie działała od 1918 r., natomiast

${ }^{51}$ APŁ, OUZP, Sprawa parcelacji państwowego majątku Orzeszków gmina Kościelnica, sygn. 497; APŁ, OUZP, Operat parcelacji majątku Orzeszków gmina Kościelnica, sygn. 498.

${ }_{52}$ T. Grabarczyk, A. Kowalska-Pietrzak, J. Szymczak, Uniejowskie strony-karty..., s. 101.

${ }_{53}$ APŁ, OUZP, Sprawa parcelacji państwowego majątku Zieleń gmina Kościelnica, sygn. 594.

${ }^{54}$ APŁ, OUZP, W sprawie parcelacji łąk Zieleń tzw. część majątku Wielenin wieś Zieleń gmina Kościelnica tom I, sygn. 571. 
budowę remizy rozpoczęto w $1924 \mathrm{r}^{55}$ Wyłączone z procesu parcelacji zostały także zabudowania folwarczne, znajdujące się na działce $n r 1^{56}$. Ponieważ istniejące budynki folwarczne były zachowane w bardzo dobrym stanie, postanowiono je przeznaczyć na szkołę rolniczą ${ }^{57}$.

Obszar nowo tworzonych gospodarstw i obszar stanowiący podstawę powiększania gospodarstw uzależniony był od miejscowych warunków gospodarczych $^{58}$. Według decyzji Okręgowego Urzędu Ziemskiego w Kaliszu z marca 1921 r. w majątku Zieleń przewidziano utworzenie 12 samodzielnych parcel i czterech parcel dodatkowych dla uzupełnienia gospodarstwa we wsi Człopy i dla powiększenia trzech gospodarstw we wsi Łęg Kościelny ${ }^{59}$. Parcele samodzielne wynosiły 13 mórg (7,28 ha) w miejscach, gdzie występowała lepsza gleba oraz 15 mórg $(8,40$ ha) na terenach o gorszych warunkach glebowych. Do wszystkich nowo utworzonych parceli w Zieleninie dodano po 2 morgi (1,12 ha) łąk i 2 morgi (112 ha) pastwiska. Parcele samodzielne rozdane zostały w większej części byłym fornalom i chłopom małorolnym, którzy byli dawnymi dzierżawcami gruntów folwarcznych w Zieleninie ${ }^{60}$.

Tabela 3. Liczba poparcelacyjnych działek według posiadanego areału w majątku Orzeszków (stan na 1921 r.)

\begin{tabular}{|c|c|}
\hline $\begin{array}{c}\text { Liczba } \\
\text { samodzielnych parcel }\end{array}$ & $\begin{array}{c}\text { Areał } \\
\text { gruntów (ha) }\end{array}$ \\
\hline 15 parcel & 8,40 \\
\hline 9 parcel & 10,08 \\
\hline 2 parcele & 8,96 \\
\hline 2 parcele & 9,52 \\
\hline Ogółem & 36,96 \\
\hline
\end{tabular}

Źródło: opracowanie własne na podstawie: APŁ, OUZP, Operat parcelacji majątku Orzeszków gmina Kościelnica, sygn. 498.

W Orzeszkowie przeznaczono 252 ha do parcelacji. Utworzono 28 samodzielnych działek o powierzchni od 15 (8,40 ha) do 18 mórg (10,08 ha) (tab. 3) oraz powiększono jedną parcelę o 2 ha dla wzmocnienia gospodarstwa M. Zielonki ze wsi Ostrowsko. Przeznaczono również 23 ha na łąki. Na zasiedlenie nowych

${ }_{55}$ T. Grabarczyk, A. Kowalska-Pietrzak, J. Szymczak, Uniejowskie strony-karty..., s. 148.

${ }^{56}$ APŁ, OUZP, W sprawie parcelacji łąk Zieleń tzw. część majątku Wielenin wieś Zieleń gmina Kościelnica tom I, sygn. 571.

${ }^{57}$ APŁ, OUZP, Sprawa parcelacji majątku państwowego Wielenin gmina Kościelnica, sygn. 572.

58 J.S. Langrod, Zarys administracji agrarnej..., s. 41.

59 APŁ, OUZP, Sprawa parcelacji państwowego majątku Zieleń gmina Kościelnica, sygn. 594.

${ }^{60}$ Tamże; APŁ, OUZP, Sprawa parcelacji majątku państwowego Zieleń-Ląki gmina Kościelnica, sygn. 596. 
28 działek w Orzeszkowie znalazło się 11 inwalidów i żołnierzy wojennych, 10 rodzin ze służby folwarcznej, 7 osób bezrolnych i jedna rodzina małorolna ${ }^{61}$. Prośby o nabycie ziem w Orzeszkowie, w celach powiększenia swoich karłowatych gospodarstw, pisali również mieszkańcy Ostrowska ${ }^{62}$.

Wstępny szkic parcelacji majątku Wielenin zakładał utworzenie 36 samodzielnych parcel oraz dwóch parcel dodatkowych, od strony północno wschodniej dla wzmocnienia gospodarstw wsi Zaborów. Projekt obejmował utworzenie w północnej części, w rejonie granicy z wsią Dąbrowa, 10 gospodarstw po 16 mórg ( 8,96 ha) i 2 parcele po 15 mórg ( 8,40 ha). Od strony wschodniej utworzono trzy parcele 15 morgowe ( 8,40 ha) i jedną o powierzchni 14 mórg (7,84 ha). Pomiędzy drogami polnymi, biegnącymi do wsi Dąbrowa i Stanisławów, zaprojektowano 5 parcel o powierzchni 14 mórg (7,84 ha). W południowej części parcelowanego majątku zaprojektowano 10 parcel 15 morgowych $(8,40 \mathrm{ha})$, dwie parcele 15,5 morgowe (8,68 ha) i 20 morgowe (11,20 ha) oraz jedną 17 morgową (9,52 ha). Warto wspomnieć, że wszystkie parcele powstały na gruntach ornych. Według decyzji Okręgowego Urzędu Ziemskiego w Kaliszu utworzono 29 parcel i 4 dodatkowe, ponadto do majątku Wielenin przydzielono parcele łąkowe z majątku Zielenin o powierzchni 10 mórg i 47 prętów $^{63}(5,60$ ha). W Wieleninie zgłosiło się 209 chętnych na objęcie nowo wytyczonych działek ${ }^{64}$. Powodami tak dużego zainteresowania nabywaniem ziem było przeludnienie wsi oraz dominacja małych gospodarstw, niewystarczających na samodzielne utrzymanie rodziny ${ }^{65}$.

Z przedstawionych danych wynika, że struktura agrarna omawianych majątków, $\mathrm{w}$ analizowanym przedziale czasowym, uległa gruntowym przeobrażeniom. $\mathrm{W}$ drodze parcelacji dawnych gruntów folwarcznych powstało około 76 nowych gospodarstw wiejskich oraz kilka zostało powiększonych. Trzeba także podkreślić, że znaczna część gruntów została przeznaczona na cele oświaty powszechnej i zawodowej.

Ciąg dalszy parcelacji miał miejsce w kolejnych latach. W 1922 r. rozparcelowano około 51 mórg (28,56 ha) łąk Rudunki ${ }^{66}$. W 1924 r. podzielono grunty pozostałych fragmentów łąk Rudunek i Łąki na Zieleniu. W obrębie Łąk na Zieleniu zaprojektowano powiększenie gospodarstw dla okolicznej ludności. Każdy gospodarz otrzymał około 0,84 ha. Z Łąk na Zieleniu po wyłączeniu powierzchni dla ośrodka w Wieleninie, dla urzędu w Kościelnicy i parafii w Spicymierzu, sygn. 498 .

${ }^{61}$ APŁ, OUZP, Sprawa parcelacji państwowego majątku Orzeszków gmina Kościelnica,

${ }^{62}$ APŁ, OUZP, $W$ sprawie wniosku parcelacyjnego w związu ze scaleniem gruntów wsi Ostrowsko, sygn. 503.

${ }^{63}$ APŁ, OUZP, W sprawie parcelacji łąk Zieleń tzw. część majątku Wielenin wieś Zieleń gmina Kościelnica tom I, sygn. 571; APŁ, OUZP, Sprawa parcelacji majątku państwowego Wielenin gmina Kościelnica, sygn. 572.

${ }^{64}$ APŁ, OUZP, Sprawa parcelacji majątku państwowego Wielenin gmina Kościelnica, sygn. 572.

${ }_{65}$ M. Machałek, Przemiany polskiej wsi..., s. 58-60.

${ }^{66}$ APŁ, OUZP, Sprawa parcelacji państwowego majątku Zieleń gmina Kościelnica, sygn. 594. 
w 1925 r. wytyczono i sprzedano mieszkańcom, którzy nabyli grunty w Wieleninie i Orzeszkowie, dodatkowe tereny ${ }^{67}$.

Po rozparcelowaniu folwarków zaczęły powstawać nowe układy przestrzenne osad. W większości była to rozproszona zabudowa, powstająca przy drogach rozmieszczonych w nieregularny sposób. W nowo powstałym Orzeszkowie - Kolonia i Wieleninie wytyczono drogi w obrębie dawnych rozłogów (możliwe, że kiedyś były to drogi polne). Jak widać na zamieszczonej mapie (ryc. 3) gospodarstwa niekiedy budowano w głębi pól i doprowadzono do nich drogi łączące się z głównymi traktami komunikacyjnymi wsi ${ }^{68}$. Zapewnienie dogodnego dojazdu do posesji było uwzględnione w planach parcelacyjnych ${ }^{69}$. W Orzeszkowie na drogi przeznaczono około 1 ha $^{70}$. Analizując dostępne źródła kartograficzne widzimy, że w Wieleninie (ryc. 4) dawne drogi polne przejęły funkcje głównych osi siedliskowych, przy których ulokowano gospodarstwa. W krajobrazie nadal czytelny był jednak dawny układ rozłogów folwarcznych ${ }^{71}$. Gospodarstwa posiadały charakter luźny, rozproszony, czasem także samotniczy. Parcelacja gruntów w badanych wsiach, w okresie międzywojennym, przyniosła efekt w postaci przyrostu osad, przez powstawanie nowych działek budowlanych i zasiedlanie drobnych fragmentów wolnych gruntów ${ }^{72}$.

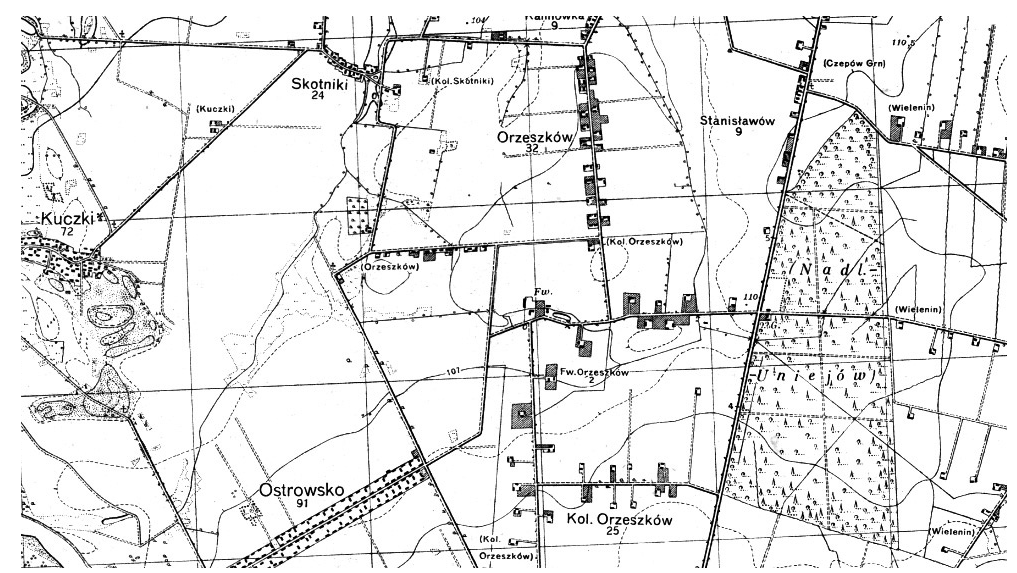

Ryc. 3. Struktura przestrzenna powstałej w drodze parcelacji Kolonii Orzeszków. Stan na 1936 r. Źródło: WIG, Mapa Szczegółowa Polski (1929-1939), 1:25 000, sygn. P40 S27 I

${ }^{67}$ APŁ, OUZP, Sprawa parcelacji majątku państwowego Zieleń-Ląki gmina Kościelnica, sygn. 596.

${ }^{68}$ WIG, Mapa Szczegółowa Polski, (1929-1939), 1:25 000, sygn. P40 S27 I.

69 J.S. Langrod, Zarys administracji agrarnej ..., s. 41.

${ }^{70}$ APŁ, OUZP, Operat parcelacji majątku Orzeszków gmina Kościelnica, sygn. 500.

${ }_{71}$ AGAD, Zbiór kartograficzny, Mapa dóbr Uniejów położonych w Gubernii i Obwodzie Kaliskim, 1838, sygn. 249-9 ark. 5, http://mapy.geoportal.gov.pl/imap/?gpmap=gp0\&action$\mathrm{s}=$ acShowServices_KATASTER, skala 1: 25 000, [dostęp: 20.02.2018].

${ }^{72} \mathrm{~J}$. Burszta, Od osady stowiańskiej do wsi współczesnej. O tworzeniu się krajobrazu osadniczego ziem polskich i rozplanowań wsi, Wrocław 1958, s. 171-172. 


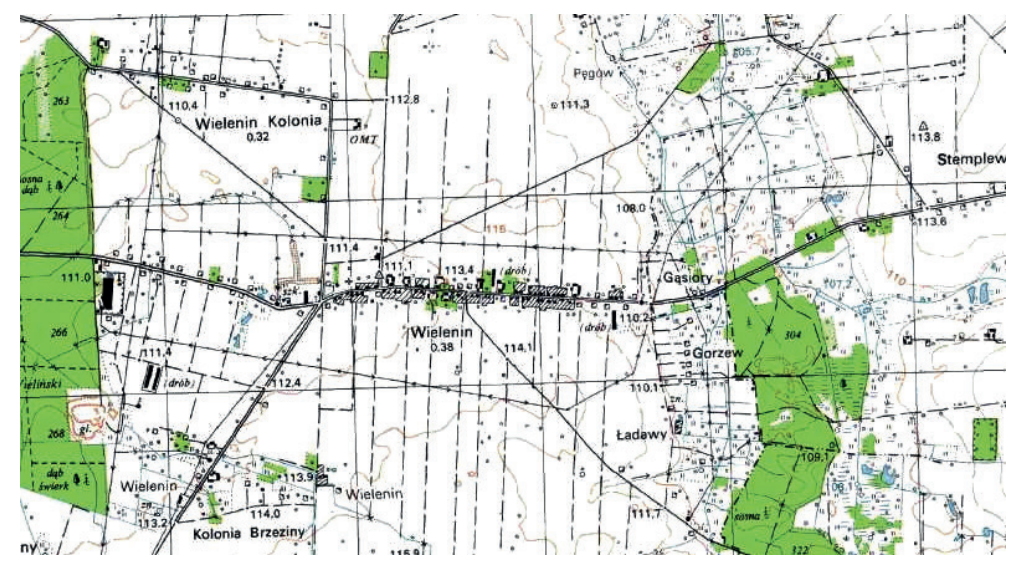

Ryc. 4. Struktura przestrzenna nowo powstałych gospodarstw w Zieleninie w okresie międzywojennym

Źródło: http://mapy.geoportal.gov.pl/imap/?gpmap=gp0\&actions=acShowServices_KATASTER, skala 1: 25000 [dostęp: 20.02.2018]

W aktach parcelacyjnych można odnaleźć także odwołania pisane przez osoby, które z różnych powodów nie otrzymały ziemi na własność. Analizując zdobyte w wyniku kwerendy archiwalnej materiały, stwierdzić można, że skargi były składane do Głównego Urzędu Ziemskiego w Kaliszu. Częstymi powodami nieprzyznania ziemi był brak dokumentów potwierdzających odbytą służbę wojskową lub brak odpowiednich kwalifikacji do pracy na roli ${ }^{73}$.

Odwołania, z uwagi na niezadowolenie z decyzji, w sprawie parcelacji pisały także instytucje państwowe. Zarząd Nadleśnictwa Uniejów wnioskował o wyłączenie z procesów parcelacji tzw. Łąk Rudunek z majątku Zieleń. Powodem odwołania było istnienie terenów torfowiskowych. Z materiałów wynika, że wystosowano odpowiedź odmowną, gdyż grunty te zostały już rozparcelowane ${ }^{74}$. Parafia z Wilanowa w 1921 r. prosiła o przyznanie proboszczowi i służbie kościelnej odpowiednich nadziałów gruntów na rozparcelowanych gruntach majątku Orzeszków ${ }^{75}$.

${ }^{73}$ APŁ, OUZP, Sprawa parcelacji państwowego majątku Orzeszków gmina Kościelnica, sygn. 498.

${ }^{74}$ APŁ, OUZP, Sprawa parcelacji majątku państwowego Zieleń-Ląki gmina Kościelnica, sygn. 596.

${ }^{75}$ APŁ, OUZP, Operat parcelacji majątku Orzeszków gmina Kościelnica, sygn. 498. 


\section{PODSUMOWANIE}

W artykule podjęto próbę ukazania specyfiki procesów parcelacji gruntów folwarcznych w okresie międzywojennym, w ujęciu mikroskalowym. Na przykładzie dawnych majątków w gminie Kościelnica, pod Uniejowem: Orzeszków, Wielenin i Zieleń udało się zobrazować szczegóły dotyczące procesu repartycji gruntów w ujęciu formalno-prawnym oraz praktycznym, uwzględniającym reperkusje osadnicze. Folwarki w gminie Kościelnica, tak jak inne wielkie majątki ziemskie w Polsce, zostały ustawowo poddane podziałom, w ramach reformy rolnej, realizowanej sukcesywnie na podstawie trzech głównych aktów prawnych. Oprócz zmian o podłożu społeczno-ekonomicznym, reforma rolna miała także ogromny wpływ na zmiany struktur przestrzennych osadnictwa, których efekty dostrzegalne są do dziś w krajobrazie wiejskim. W związku z parcelacją gruntów folwarcznych oraz powstaniem nowych siedlisk, wsie podlegały wyraźnej regulacji, a część z nich przyjęła zupełnie nowe formy rozplanowania.

\section{Bibliografia}

Bandurka M., Zmiany administracyjne i terytorialne ziem województwa tódzkiego w XIX $i$ XX w. (wyd. II uzupełnione), Łódź 1995.

Biernacka M., Oświata a spoteczno-kulturowe przeobrażenia wsi $w$ okresie międzywojennym (na przykładzie wybranych społeczności), „Etnografia Polska” 1983, t. 27, z.1, s. 103-131.

Burszta J., Od osady stowiańskiej do wsi współczesnej. O tworzeniu się krajobrazu osadniczego ziem polskich i rozplanowań wsi, Wrocław 1958.

Cepil M., Figlus T., Geneza majoratu i stosunki osadnicze w dobrach rodziny Tollów pod Uniejowem, „Biuletyn Uniejowski” 2017, t. 6, s. 91-107.

Firlej K., Formy organizacyjne zagospodarowania ziem polskich na przestrzeni wieków, „Roczniki Ekonomiczne Kujawsko-Pomorskiej Szkoły Wyższej w Bydgoszczy” 2011, nr 4, s. 21-36.

Grabarczyk T., Kowalska-Pietrzak A., Szymczak J., Uniejowskie strony-karty z przeszłości odległej, nieznanej i bliskiej gminy Uniejów, Łódź-Uniejów 2008.

Kłusek M., Definicja nieruchomości ziemskiej $w$ aktach prawnych $i$ orzecznictwie sqdowym 20-lecia międzywojennego, „Studia z zakresu Prawa, Administracji i Zarządzania” 2015, t. 8, s. 91-113.

Konopka K., Konieczność reform agrarnych w Drugiej Rzeczypospolitej Polskiej, „Economy and Management" 2009, 1, s. 7-19.

Konopka K., Mechanizm reform agrarnych w Drugiej Rzeczypospolitej Polskiej (1918-1939), Oficyna Wydawnicza Politechniki Białostockiej, Białystok 2010.

Kowalik-Bodzak D., Wpływ podziału spadkowego, komasacji i parcelacji na zmianę układów przestrzennych wsi w powiecie puławskim od połowy XIX w., „Dokumentacja Geograficzna” 1964, z. 4, s. 97-152.

Kukulski J., Generałowie carscy i ich majątki ziemskie w Królestwie Polskim (1835-1920), Wyd. Neriton, Warszawa 2007. 
Langrod J.S., Zarys administracji agrarnej w Polsce, Kraków-Warszawa 1939.

Machałek M., Przemiany polskiej wsi w latach 1918-1989, „Klio. Czasopismo poświęcone dziejom Polski i powszechnym" 2013, t. 26 (3), s. 55-80.

Mieszczankowski M., Rolnictwo II Rzeczypospolitej, Książka i Wiedza, Warszawa 1983.

Myszkorowska-Olczak G., Zespoły folwarczne na terenie gminy Uniejów, „Biuletyn Uniejowski” 2013, t. 2, s. 93-112.

Noniewicz Cz., Reforma rolna na Wileńszczyźnie w okresie międzywojennym, „Optimum. Studia Ekonomiczne" 2014, nr 6 (72), s. 93-112.

Prochownik A., Przemiany struktury osadniczo-agrarnej wsi powiatu proszowickiego od połowy XIX wieku do 1960 r. (na wybranych przyktadach), „Dokumentacja Geograficzna” 1965, z. 6, s. 159.

Staniewicz W., Zmiany w strukturze agrarnej Polski, „Ruch Prawniczy, Ekonomiczny i Socjologiczny" 1936, nr 4, s. 382-397.

Stelmachowski A. (red.), Prawo rolne, Wyd. LexisNexis, Warszawa 2006.

Ziętara W., Społeczny czy ekonomiczny charakter reform rolnych w Polsce w okresie między- i powojennym, „Roczniki Naukowe Ekonomii Rolnictwa i Rozwoju Obszarów Wiejskich” 2015, t. 102 , z. 1, s. 31-45.

\section{Źródla}

Archiwum Główne Akt Dawnych w Warszawie, Zbiór kartograficzny, Mapa dóbr Uniejów położonych w Gubernii i Obwodzie Kaliskim, 1838, sygn. 249-9, ark. 5.

Archiwum Główne Akt Dawnych w Warszawie, Zbiór kartograficzny, Plan wsi i folwarku Wielenin z 1839 r., sygn. 185-1, ark. 45.

Archiwum Główne Akt Dawnych w Warszawie, Zbiór kartograficzny, Plan wsi i folwarku Zielenin z 1839 r., sygn. $185-1$, ark. 27.

Archiwum Państwowe w Łodzi, Okręgowy Urząd Ziemski w Piotrkowie, Operat parcelacji majątku Orzeszków gmina Kościelnica, sygn. 498.

Archiwum Państwowe w Łodzi, Okręgowy Urząd Ziemski w Piotrkowie, Sprawa parcelacji państwowego majątku Orzeszków gmina Kościelnica, sygn. 497.

Archiwum Państwowe w Łodzi, Okręgowy Urząd Ziemski w Piotrkowie, Sprawa parcelacji państwowego majątku Zieleń gmina Kościelnica, sygn. 594.

Archiwum Państwowe w Łodzi, Okręgowy Urząd Ziemski w Piotrkowie, Sprawa parcelacji majątku państwowego Zieleń-Ląki gmina Kościelnica, sygn. 596.

Archiwum Państwowe w Łodzi, Okręgowy Urząd Ziemski w Piotrkowie, Sprawa parcelacji majątku państwowego Wielenin gmina Kościelna, sygn. 570.

Archiwum Państwowe w Łodzi, Okręgowy Urząd Ziemski w Piotrkowie, W sprawie parcelacji tąk Zieleń tzw. część majątku Wielenin wieś Zieleń gmina Kościelnica tom I, sygn. 571.

Archiwum Państwowe w Łodzi, Okręgowy Urząd Ziemski w Piotrkowie, Sprawa parcelacji majątku państwowego Wielenin gmina Kościelnica, sygn. 572.

Archiwum Państwowe w Łodzi, Okręgowy Urząd Ziemski w Piotrkowie, $W$ sprawie wniosku parcelacyjnego w związu ze scaleniem gruntów wsi Ostrowsko, sygn. 503.

Konstytucja Rzeczypospolitej Polskiej z dn. 17 marca 1921 r. (Dz.U. 1921, nr 44, poz. 267).

Monitor Polski, nr 217, dn. 30 listopada 1918 r. 
Parcelacja i Osadnictwo (parę stów o reformie rolnej), Towarzystwo Oświaty Narodowej, Warszawa 1921.

Skorowidz miejscowości Rzeczypospolitej Polskiej, województwo łódzkie, t. II, Warszawa 1925. Ustawa z dn. 4 listopada 1918 r. w przedmiocie dóbr donacyjnych (Dz.U. 1918, nr 15, poz. 35).

Ustawa z dn. 6 lipca 1920 r. o organizacji urzędów ziemskich (Dz.U. 1920, nr 70, poz. 461).

Ustawa z dn. 15 lipca 1920 r. o wykonaniu reformy rolnej (Dz.U. 1920, nr 70, poz. 462).

Ustawa z dn. 28 grudnia 1925 r. o wykonaniu reformy rolnej (Dz.U. 1926, nr 1, poz. 1).

Wojskowy Instytut Geograficzny, Mapa Szczegółowa Polski, (1929-1939), 1:25 000, sygn. P40 S27 I

\section{Źródła internetowe}

http://mapy.geoportal.gov.pl/imap/?gpmap=gp0\&actions=acShowServices_KATASTER, skala 1:25 000 [dostęp: 20.02.2018].

[Artykuł wpłyną: maj 2018; akceptacja: czerwiec 2018]

\section{PARCELLING OUT OF RURAL LAND IN THE INTERWAR PERIOD AND ITS CONSEQUENCES FOR SETTLEMENT - EXAMPLES OF ORZESZKÓW, WIELENIN AND ZIELEŃ}

\section{Summary}

The article presents the results of research on the process of parcelling out the land of big farms in Uniejów region in the interwar period. The analysis covered three settlement units in located in the former commune of Kościelnica: Orzeszków, Wielenin and Zielen. The first part of the article explains some legal aspects of the parcellation process connected with the implementation of the land reform. The next part presents the results of research on the parcellation of villages in the commune of Kościelnica, including legal questions and changes in the spatial structures of settlement.

Keywords: historical geography, settlement, village, big farms, parcelling out, land reform, interwar period, commune of Kościelnica 